Kong. Res. J. 2(1) : 88-93, 2015

ISSN 2349-2694

Kongunadu Arts and Science College, Coimbatore.

\title{
SURVEY OF CLIMBERS IN ATCHANKULAM, KOTTARAM PANCHAYAT, KANYAKUMARI DISTRICT, TAMILNADU, INDIA.
}

\author{
Mary Kensa, V. ${ }^{*}$, BeemaJainab, S.J. ${ }^{2}$, Kavitha, A. ${ }^{1}$, Rejitha,S. ${ }^{1}$, Anusha M. ${ }^{1}$ and Vinitha, R. ${ }^{1}$ \\ ${ }^{1}$ Department of Botany and Research Centre, S.T. Hindu College, Nagercoil-629 002, Tamil Nadu, India \\ 2J.B.A.S.College for women (Autonomous), Chennai-18. \\ *E.mail: surejkensa@gmail.com
}

\begin{abstract}
Climbing plants are one of the most interesting group but a much neglected group of plants. But, they also play a part in historical importance of our ancient buildings which owe their attraction to the green veil which covers up their architectural or structural defects making them assume perfect beauty in our eyes. The present survey reveals that angiospermic climbers of the study area are represented by 94 species under 63 genera belonging to 32 families. Among all families, Convolvulaceae, Papilionaceae 7 species) and Vitaceae are the most dominating family species as well as genera wise. The dominant families are Convolvulaceae, Papilionaceae, Vitaceae, Apocynaceae, Menispermaceae and Oleaceae. The most abundant liana species include the thorny stragglers Pterolobium hexapetalun (Caesalpiniaceae), Lantana camara (Verbenaceae), and the twiners Jasminum angustifolium (Oleaceae), Gymnena sylvestre (Asclepiadaceae) and Aganosmacymosa var. cymosa (Apocynaceae). The enumerated climbing modes were classified into woody vines, the lianas (75) and herbaceous vines (19). Six climbing modes of lianas were recognized as stem twiners (37) followed by stragglers-unarmed (28), stragglers unarmed (10), tendril climbers (17), root climbers (1) and hook climber (1).
\end{abstract}

Key words: Climbing plants, Atchankulam, Survey.

\section{INTRODUCTION}

Climbing plants are defined as plants incapable of autonomous vertical support once they reach a certain height and depend on other plants for support in their natural environment (Gentry, 1991). The climbing habit has arisen several times in the evolutionary history of Angiosperms, and this has resulted in a great taxonomic diversity of climbing plants (Gentry, 1985). Families such as Smilacaceae, Menispermaceae, Passifloraceae, Cucurbiaceae and Convolvulaceae are essentially entirely composed of or dominated by species with a climbing habit. Climbing plants are an interesting but much neglected group. This group consists of plants that are rooted in the ground but need support for their weak stems, and both herbaceous (vines) and woody (lianas) climbing plants can be found. Recent reviews of the role of climbers in forest ecosystems (Putz and Mooney, 1991; Schnitzer and Bongers, 2002; Wright et al., 2004; Phillips et al., 2005) have highlighted the abundance, competitive abilities, and contribution to disturbance regimes. Today, climbing plants typically contribute $2-15 \%$ of the leaf biomass and about $5 \%$ of the wood biomass to forests (Fearnsideet al., 1999; Gerwing and Farias, 2000; Clark et al., 2008). In climber-rich areas, they can contribute as much as $40 \%$ of the estimated total biomass (Hegarty and Caballe, 1991; PerezSalicrupet al., 2001). Climbers not only form important structural components but also play an important ecological role in forest dynamics, diversity and nutrient recycling (Gentry and Dodson 1987; Schnitzer and Bongers, 2002). No comprehensive work is available for climbers in the study area. Therefore, the objective of the present study is to document the angiospermic climbers of Atchankulam, KottaramPanchayat, Kanyakumari District.

\section{MATERIALS AND METHODS}

\subsection{Description of the Study Area}

The present study was carried out in Atchankulam of KottaramPanchayat and AgastheeswaramTaluk of Kanyakumari District. This District constitute the southernmost step of India, with Kerala on the West-North, Tirunelveli District in the North-East Arabian sea in the South West, Bay of Bengal in the south-East and Indian ocean in the south. The annual rainfall of this area is low when compared to other areas of the Kanyakumari District. There are nearly 1450 families are live in this panchayat. Most of the people are coolies or farmers. 


\subsection{Floristic Survey}

The present study was carried out through intensive and extensive field visits during January 2014-July 2014. During field survey, the plants have been collected in their flowering and fruiting stages as far as possible from the natural habitats. They are identified with the help of local floras (Gamble and Fischer 1015-1936; Matthew 1983; Nair and Henry 1983; Henry et al., 1987; 1989; Chandrabose and Nair 1988). Further the identities were confirmed is referring authentic specimens and the voucher specimens deposited in the Herbarium of Department of Botany, South Travancore Hindu College, Nagercoil.

\section{Table 1: Angiosperm climbing plants enumerated from the study area, binomial, family, category and climbing mode.}

\begin{tabular}{|c|c|c|c|}
\hline $\begin{array}{l}\text { S. } \\
\text { No. }\end{array}$ & Species / Family & Category & $\begin{array}{r}\text { Climbing } \\
\text { Mode } \\
\end{array}$ \\
\hline 1 & $\begin{array}{l}\text { Annonaceae } \\
\text { Desmosviridiflora(Bedd.) Safford } \\
\text { Apocynaceae }\end{array}$ & WV & Str-UA \\
\hline 2 & $\begin{array}{l}\text { Aganosmacymosa(Roxb) G. Don } \\
\text { var. Cymosa }\end{array}$ & WV & ST \\
\hline 3 & AnodendronpaniculatumA.DC. & WV & ST \\
\hline 4 & Carissa gangeticaStapf & WV & Str-A \\
\hline 5 & Carissa salicinaLam. & WV & Str-A \\
\hline 6 & $\begin{array}{l}\text { Carissa spinarumL. } \\
\text { Aristolochiaceae }\end{array}$ & WV & Str-A \\
\hline 7 & $\begin{array}{l}\text { AristolochiaindicaL. } \\
\text { Asclepiadaceae }\end{array}$ & $\mathrm{HV}$ & ST \\
\hline 8 & $\begin{array}{l}\text { Gymnemasylvestre(Retz.) R.Br.ex } \\
\text { Roemer \&Schultes }\end{array}$ & WV & ST \\
\hline 9 & Hemidesmusindicus(L) R. Br. & $\mathrm{HV}$ & ST \\
\hline 10 & Pergulariadaemia(Forssk.) Chiov. & HV & ST \\
\hline 11 & $\begin{array}{l}\text { Sarcostemmaacidum(Roxb.) Voigt } \\
\text { Caesalpiniaceae }\end{array}$ & WV & Str-UA \\
\hline $\begin{array}{l}12 \\
13\end{array}$ & $\begin{array}{l}\text { Caesalpinia crista L. } \\
\text { CaesalpiniacucullataRoxb. }\end{array}$ & $\begin{array}{l}\text { WV } \\
\text { WV }\end{array}$ & $\begin{array}{l}\text { Str-A } \\
\text { Str-A }\end{array}$ \\
\hline 14 & $\begin{array}{l}\text { Pterolobiumhexapetalum(Roth) } \\
\text { Sant. \&Wagh } \\
\text { Capparaceae }\end{array}$ & WV & Str-A \\
\hline $\begin{array}{l}15 \\
16\end{array}$ & $\begin{array}{l}\text { CapparisbrevispinaDC. } \\
\text { CapparissepiariaL. }\end{array}$ & $\begin{array}{l}\text { WV } \\
\text { WV }\end{array}$ & $\begin{array}{l}\text { Str-A } \\
\text { Str-A }\end{array}$ \\
\hline 17 & $\begin{array}{l}\text { CappariszeylanicaL. } \\
\text { Celastraceae }\end{array}$ & WV & Str-A \\
\hline 18 & CelastruspaniculatusWilld. & WV & Str-UA \\
\hline 19 & Maytenusheyneana(Roth) & WV & Str-A \\
\hline 20 & $\begin{array}{l}\text { Raju\&Babu } \\
\text { Maytenusroyleanus(Wallich ex M. }\end{array}$ & WV & Str-A \\
\hline 21 & $\begin{array}{l}\text { Lawson) M.A.Rau. } \\
\text { SalaciachinensisL. } \\
\text { Combretaceae }\end{array}$ & WV & Str-UA \\
\hline 22 & CombretumacuminatumLam. & WV & $\mathrm{TC}$ \\
\hline 23 & $\begin{array}{l}\text { CombretumalbidumG. Don } \\
\text { Convolvulaceae }\end{array}$ & WV & ST \\
\hline $\begin{array}{l}24 \\
25\end{array}$ & $\begin{array}{l}\text { Argyreiaelliptica(Roth) Choisy } \\
\text { ArgyreiainvolurataClarke }\end{array}$ & $\begin{array}{l}\text { WV } \\
\text { WV }\end{array}$ & $\begin{array}{l}\text { ST } \\
\text { ST }\end{array}$ \\
\hline 26 & $\begin{array}{l}\text { Ipomoea asarifolia(Desr.) Roem. } \\
\text { \&Schultes }\end{array}$ & $\mathrm{HV}$ & ST \\
\hline $\begin{array}{l}27 \\
28\end{array}$ & $\begin{array}{l}\text { Ipomoea companulata } \mathrm{L} . \\
\text { Ipomoea eriocarpa } \mathrm{R} . \mathrm{Br} \text {. }\end{array}$ & $\begin{array}{l}\text { WV } \\
\text { WV }\end{array}$ & $\begin{array}{l}\text { ST } \\
\text { ST }\end{array}$ \\
\hline 29 & $\begin{array}{l}\text { Ipomoea } \\
\text { staphylinaRoem\&Schultes }\end{array}$ & WV & ST \\
\hline
\end{tabular}

F.

Cucurbitaceae

31 Cocciniagrandis(L) J Voigt

32 Kedrostiscourtallensis(Arn.) WV Jeffrey

33 TrichosanthesanaimalaiensisBedd. WV TC

Dioscoreaceae

34 DioscoreaoppositifoliaL. DioscoreapentaphyllaL.

36 Dioscoreatomentosa]. Koenig ex Sprengel

Euphorbiaceae

$37 \quad$ Phyllanthusreticulatuspoir.

38 TragiainvolucrataL.

39 TragiaplukenetiiR. Smith

Liliaceae

40 Asparagus racemosusWilld.

Linaceae

41 HugoniamystaxL.

Malpighiaceae

$42 \quad$ Hiptagebenghalensis(

Menispermaceae

43 Anamirtacocculus(L) Wight \&Arn.

CissampelospareiraL.

Cocculushirsutus(L) Diels

Cycleapeltata(Lam.) Hook.f.

\&Thoms.

Pachygone

Hook.

Mimosaceae

48 Acacia pennata(L.) Willd.

Acacia sinuata(Lour.) Merr.

Acacia tortao(Roxb) Craib

Mimosa intsiaL.

Nyctaginaceae

$52 \quad$ Pisonia aculeate $\mathrm{L}$.

Oleaceae

53 Jasminumangustifolium(L.) Willd.

54 JasminumauriculatumVahl

JasminumcuspidatumRottl.

JasminummalabaricumWight

57 JasminumtrichotomumHeyne ex

Roth

Papilionaceae

58 AbrusprecatoriusL.

59 ButeaparvifloraRoxb.

60 DalbergiacongestaGraham ex

Wight \&Arn.

61 DalbergiarubiginosaRoxb.

62 MucunamonospermaDC.ex Wight

63 Mucunapruriens(l.)DC

64 Pseudarthria viscid (1.) Wight

\&Arn.

Passifloraceae

65 PassiflorafoetidaL.

66 Passiflorasubpeltata0rtega

Piperaceae

67 Piper nigrum $\mathrm{L}$.

Ranunculaceae

68 Naraveliazeylanica(l.) DC.

Rhamnaceae

69 Sageretiafiliformis(Schultes) Don

Scutiamyrtina(Burm.f.) Kurz

ZiziphushorridaRoth

72 ZiziphusrugosaLam.

Rosaceae

73 RubusellipticusSmith

Rubiaceae
ST

TC

TC

$\stackrel{H V}{H V} \quad$ ST

HV ST

WV

WV ST

HV ST

HV

Str-A

WV

HC

WV

Str-UA

WV

HV

WV

HV

WV

ST

ST

ST

ST

ST

WV

WV

WV

WV

WV

WV

WV

WV

WV

WV

Str-A

Str-A

Str-A

Str-A

Str-A

ST

ST

ST

ST

ST

WV

ST

Str-UA

WV

ST

WV

WV

WV

HV

ST

ST

ST

ST

HV TC

HV TC

WV RC

WV TC

WV Str-A

WV Str-A

WV Str-A

WV Str-A

WV Str-A 


\begin{tabular}{|c|c|c|c|}
\hline 74 & MorindaumbellataL. & WV & ST \\
\hline 75 & $\begin{array}{l}\text { Mussaendahirsutissima(Hook.f.)ex } \\
\text { Gamble }\end{array}$ & WV & ST \\
\hline 76 & $\begin{array}{l}\text { RubiacordifoliaL. } \\
\text { Rutaceae }\end{array}$ & $\mathrm{HV}$ & Str-UA \\
\hline 77 & ParamignyabeddomelTanaka & WV & Str-A \\
\hline 78 & Toddaliaasiatica(L.) Lam. & WV & Str-A \\
\hline 79 & $\begin{array}{l}\text { ZanthoxylumovalifoliumWight } \\
\text { Sapindaceae }\end{array}$ & WV & Str-A \\
\hline 80 & CardiospermumcanescensWall. & HV & TC \\
\hline 81 & $\begin{array}{l}\text { CardiospermumhalicacabumL. } \\
\text { Smilacaceae }\end{array}$ & $\mathrm{HV}$ & TC \\
\hline 82 & $\begin{array}{l}\text { Smilax zeylanicaL. } \\
\text { Tiliaceae }\end{array}$ & $\mathrm{HV}$ & TC \\
\hline 83 & Grewiaflavescensjuss. & WV & Str-UA \\
\hline 84 & $\begin{array}{l}\text { Grewia obtuse Wall } \\
\text { Verbenaceae }\end{array}$ & WV & Str-UA \\
\hline 85 & Lantana camaraL. & WV & Str-A \\
\hline 86 & $\begin{array}{l}\text { Premnacorymbosa(Burm.f.) } \\
\text { Rottler\&Willd. }\end{array}$ & WV & Str \\
\hline 87 & $\begin{array}{l}\text { Premnavillosaclark } \\
\text { Vitaceae }\end{array}$ & WV & Str \\
\hline 88 & $\begin{array}{l}\text { Ampelocissusaraneosa(Dalz. } \\
\text { \&Gibs.). }\end{array}$ & WV & TC \\
\hline 89 & $\begin{array}{l}\text { Ampelocissustomentosa(Heyne ex } \\
\text { Roth) Planch. }\end{array}$ & WV & TC \\
\hline 90 & $\begin{array}{l}\text { Cayratiapedata(Lour.) A.L. Juss. } \\
\text { Ex Gagnep. }\end{array}$ & WV & TC \\
\hline 91 & $\begin{array}{l}\text { Cayratiaroxburghii(Wight \&Arn.) } \\
\text { Gagnep. }\end{array}$ & WV & TC \\
\hline 92 & Cissusgigantea(Bedd.) Planch. & WV & TC \\
\hline 93 & CissusquadrangularisL. & WV & TC \\
\hline 94 & Cissusvitiginea $\mathrm{L}$. & WV & $\mathrm{TC}$ \\
\hline
\end{tabular}

WV: Woody vines; HV: Herbaceous vines; ST: Stem twiners, Str-A: Stragglers -armed; Str-UA: Stragglers - unarmed, TC: Tendril climbers, RC: Root climbers, and HC: Hook climber.

Table 2: Family wise and Taxonomic data of distribution of identified plants.

\begin{tabular}{|c|c|c|c|c|}
\hline$S_{\text {I.Ivo }}$ & ramily & $\begin{array}{c}\% \\
\text { composition }\end{array}$ & $\begin{array}{c}\text { Number } \\
\text { or } \\
\text { species }\end{array}$ & $\begin{array}{c}\text { Number } \\
\text { or } \\
\text { genus } \\
\end{array}$ \\
\hline 1 & Annonaceae & 1.06 & 1 & 1 \\
\hline 2 & Apocynaceae & 5.31 & 5 & 3 \\
\hline 3 & Aristolochiaceae & 1.06 & 1 & 1 \\
\hline 4 & Asclepiadaceae & 4.25 & 4 & 4 \\
\hline 5 & Caesalpiniaceae & 3.19 & 3 & 2 \\
\hline 6 & Capparaceae & 3.19 & 3 & 2 \\
\hline 7 & Celastraceae & 4.25 & 4 & 1 \\
\hline 8 & Combretaceae & 2.12 & 2 & 2 \\
\hline 9 & Convolvulaceae & 7.44 & 7 & 3 \\
\hline 10 & Cucurbitaceae & 3.19 & 3 & 3 \\
\hline 11 & Dioscoreaceae & 3.19 & 3 & 3 \\
\hline 12 & Euphorbiaceae & 3.19 & 3 & 2 \\
\hline 13 & Liliaceae & 1.06 & 1 & 1 \\
\hline 14 & Linaceae & 1.06 & 1 & 1 \\
\hline 15 & Malpighiaceae & 1.06 & 1 & 1 \\
\hline 16 & Menispermaceae & 5.319 & 5 & 5 \\
\hline 17 & Mimosaceae & 4.25 & 4 & 2 \\
\hline 18 & Nyctaginaceae & 1.06 & 1 & 1 \\
\hline 19 & Oleaceae & 5.31 & 5 & 1 \\
\hline 20 & Papilionaceae & 7.44 & 1 & 1 \\
\hline 21 & Passifloraceae & 2.12 & 2 & 1 \\
\hline 22 & Piperaceae & 1.06 & 1 & 1 \\
\hline 23 & Ranunculaceae & 1.06 & 1 & 1 \\
\hline 24 & Rhamnaceae & 4.25 & 4 & 3 \\
\hline 25 & Rosaceae & 1.06 & 1 & 1 \\
\hline 26 & Rubiaceae & 3.19 & 3 & 3 \\
\hline
\end{tabular}

\begin{tabular}{lllll}
\hline 27 & Rutaceae & 3.19 & 3 & 3 \\
28 & Sapindaceae & 2.12 & 2 & 1 \\
29 & Smilacaceae & 1.06 & 1 & 1 \\
30 & Tiliaceae & 2.12 & 2 & 1 \\
31 & Verbenaceae & 3.19 & 3 & 2 \\
32 & Vitaceae & 7.44 & 7 & 3 \\
\hline
\end{tabular}

Table 3. Dominant families of identified plants

\begin{tabular}{llll}
\hline Sl.No & \multicolumn{1}{c}{ Family } & Number of Plants \\
\hline 1. & Convolvulaceae & 7 & \\
2. & Papilionaceae & 7 & \\
3. & Vitaceae & 7 & \\
4. & Apouynaceae & 5 & \\
5. & Menispermaceae & 5 & \\
6. & Oleaceae & 5 & \\
\hline
\end{tabular}

Table 4. Distribution of identified plants under climbing mode

\begin{tabular}{lllc}
\hline Sl.No & Climbing mode & Number of plants & \% \\
\hline 1 & Woody vines & 75 & 79.8 \\
2 & Herbaceous vines & 19 & 20.2 \\
\hline
\end{tabular}

\section{RESULTS AND DISCUSSION}

The present survey reveals that angiospermic climbers of the study area are represented by 94 species under 63 genera belonging to 32 families (Table-1 and 2) Among all families, convolvulaceae, papilionaceae ( 7 species) and vitaceae are the most dominating family species as well as genera wise (Table- 3). The dominant families are Convolvulaceae, Papilionaceae, Vitaceae, Apocynaceae, Menispermaceae and Oleaceae (Table 3).

The most abundant liana species include the thorny stragglers Pterolobium hexapetalun (Caesalpiniaceae), Lantana camara(Verbenaceae), and the twiners Jasminum angustifolium (Oleaceae), Gymnena sylvestre (Asclepiadaceae) and Aganosma cymosa var. cymosa (Apocynaceae). The enumerated climbing modes were classified into woody vines, the lianas (75) and herbaceous vines (19) (Table - 4). Six climbing modes of lianas were recognized as stem twiners (37) followed by stragglers-unarmed (28), stragglers unarmed (10), tendril climbers (17), root climbers (1) and hook climber (1).

Plasticity in eco-physiological traits has been related to the ecological breadth of forest forms (Saldana et al., 2005) and shrubs (Valladareset al., 2000) but this issue has not been addressed for climbing plants. It is verified that climbers and rest supporting species would share functional strategies to successfully cope with light heterogeneity, despite the intrinsic differences between these growth forms (Rowe and speck, 2005). It has been earlier shown that climbing plants exhibit life history trade-offs along forest light environments similar to those of trees (Gilbert et al.,2006) and that the relationship between photosynthetic rate and dark respiration is 
comparable among lianas and trees (Domingueset al., 2007). Because earlier work has suggested possible differences in the ecology of climbing plants in tropical and temperate rain forests.

This result is consistent with the conclusion of Rundel and Franklin (1991), who in their study on vines of arid and semiarid environments, reported that the great majority of arid zone climbers are herbaceous (Vines) .while woody climbers are rare. Even though Olaxscandens (Oleaceae), Chilocarpusatrovinens (Apocynaceae), Artabtryszeylamicus (Annonaceae) and Calamusgamblei (Arecaceae) were reported as most abundant species in the western Ghats and Strychnos minor (Loganiaceae) in the tropical dry evergreen forests on the colonnade coast of India (Parthasarathyet al., 2004) these species did not occur in the study site. Only one climbing mode, the grapnel-like climbing (rattans) which was reported from Indian Western Ghats sites (Muthuramkumar and Parthasarathy, 2000) did not occur in our study sites.

Presently, plant vegetation's are subjected to various anthropogenic pressures and the data so plant diversity such as this on lianas will be useful in highlighting the importance of this vegetation in species conservation and management.

Contrary to findings from tropical forests (Balfour and Bond, 1993, Sridhar Reddy and Parthasarathy, 2003, Dewaltet al., 2006, Yan et al., 2006) trees were not represented among the 94 climbing plants of study area. According to EL Hadidiet al., (1992) some climbing plants were considered endangered, including Cadapafarinosa, Maeruaoblongifolia, Ephedra foemina and Plicosepaluscurviflorus. Tackholm (1974) considered another climbingg plant species to be very rare (eg. Podostelma schimperi, Merremiasemis agittata, Corallocarpus suhimperi, Kedrostis foetidissima, Corallocarpus schimperi, Kedrostis foetidissima, Cissus quadragularis, Peatatropis rivalis and Pergularia daemia)

The comparison between the members of desert climbing plants in Egypt and those of deserts in other continents revealed that ConvolvulaceaeLeguminosae, Cucurbitaceae and Asclepiadaceae were the dominant plant families (Parsons, 2005). In the present survey Convolvulaceae, Papilionaceae and Vitaceae are the dominant families Speciation in the family Convolvulaceae, has been more prolific in the Desert of India where it is the fourth largest family of vascular flora (Shmida, 1985). Vitaceae, the fifth largest vine family in the North American deserts were poorly represented in the Egyptian deserts but not known at all in Australian deserts. Australia has only about 34 species of the approximately 700 species of vitaveae found worldwide (Morley and Toelken, 1983), the family being considered Laurasian (Krings, 2000).

It has been reported that woody vines are increasing in dominance, relative in both tropical (Philips et al., 2002; Wright et al., 2004 and Swaine and Graace, 2007) and temperate forests (Allen et al, 2007). This pattern has been related to climate change (Malhi and Wright, 2004, Vander et al., 2008). One of the global change drivers (Matesaazet al., 2010) but more comprisal evidence is needed. Schnitzer, (2005) reported that the abundance of woody vines in tropical forests is correlated negatively with precipitation and positively with seasonality. He further proposed that this pattern may be explained by the greater efficiency in water uptake and transport of woody climbers as compared to trees. Our study area is a wet, cold (Dorsch, 2003) where light availability is the major ecological factor affecting distribution and abundance of trees (Lusk et al., 2006, Lusk, 2002 and Saldana of Lusk, 2003) but not woody vines (Gianoliet al., 2010, Carrasco et al.,(2009) in the temperate rainforest, where the potential evapotranspiration is very low, water availability is not a limiting factor and therefore water use features are was likely to determine plant distribution and abundance. From an applied perspective, the results of the present study suggest that the dominant climbers in the southern temperate rainforest could be able to cope with another global change driver, and use change if forest clearing occurs due to human activities.

Because climbers are present in so many ecosystems today, the morphological characteristics of the climber communities in disturbed versus stable, wetland versus well drained and open versus shaded forest ecosystems should help us recreate the distribution and importance of climbers in ecosystems throughout the last 30 million years. However, destruction of habitat through deforestation and over exploitation for commercial purposes and changes in cultural attitude threatens to constrain many of these climbers in to extinction.

Over exploitation of some climber species particularly collection of roots and underground parts from the climbers causes damage to these plants. Therefore, there are a people for the importance as well as conservation of these climbers in their original habitat. Climber abundance is dependent on climate and forest structure. Site with short or absent dry season have. We propose that a great heterogeneity of potential sites for climbers, thus also increasing, their richness. It is possible that sites with different dry season combined with 
tree heterogeneity can enhance the rates of climber speciation.

\section{REFERENCES}

Allen, B.P., R.R. Sharitz and P.C. Goebel, (2007). Are lianas increasing in importance in temperate floodplain forests in the south-eastern United States? Forest Ecology Management 242: 17-23.

Balfour, A.D. and W.J. Bondm, (1993). Factors limiting climber distribution and abundance in a Southern African forest. Journal of Ecology 81: 93-99.

Carrasco-Urra, F. and E. Gianoli, (2009). Abundance of climbing plants in a southern temperate rainforest: host-tree characteristics or light availability? Journal of Vegetaion Science 20: 1155-1162.

Chandrabose, M. and N.C. Nair, (1988). Flora of Coimbatore. Bishen Singh Mahendra Palsingh, Dehra Dun.

Clark, D.B., P.C. Olivas, S.F. Oberbauer, D.A. Clark and M.G. Ryan, (2008). First direct landscape-scale measurement of tropical rain forest leaf area index, a key driver of globl primary productivity. Ecology letters 11: 163-172.

Dewal, S.J., K. Ickes, R. Nilus, K.E. Harms and D.F. Burslem, (2006). Liana habitat associations and community structure in a Bornean Lowland tropical forest. Plant Ecology 186: 203-216.

Domingues, T.F., L.A. Martinelli and J.R. Ehleringer, (2007). Ecophysiological traits of plant functional groups in forest and pasture ecosystems from eastern Amazônia, Brazil. Plant Ecology 193: 101-112.

Dorsch, K., (2000). Hydrogeslogischeuntersuchungan der Geothermalfelder Von Puyehue and Cordon Caudle, Chile, Ph.D. Dissertation. Ludwing Maximilians - Universitat, Munchen.

EL Hadidi, M.N., M.M. Abd E1-Ghani and A.G. Fahmy, (1992). The plant Red Data Book of Egypt. I Woody perennials. Cairo: Palm Press and Cairo University Herbarium. Ecology 5: 1345-1353

Feamside, P.M., P.M.L.A. Graça, N. Leal Filho, F.J.A. Rodrigues and J.M. Robinson, (1999). Tropical forest burning in Brazilian Amazonia: measurements of biomass loading, burning efficiency and charcoal formation at Altamira, Para. Forest Ecology and Management 123(1): 65-79.

Gamble, J.S. and C.E.C. Fisher, (1915-1936). Flora of the presidency Madras. Vol. I-III, Adlard\& Co. London (Reprinted 1956). Botanical Survey of India. Calcutta.
Gentry, A.H., (1985). An ecotaxonomic survey of Panamanian lianas In: D'Arey, W. and Correa M. (Eds.), Historia natural de panama Monograph of systematic Botany, Missouri Botanical garden saint Louis pp.29-42

Gentry, A.G., (1991). The distribution and evolution of climbing plants. InF.E. Putz and H.A. Mooney [eds.], The biology of vines, 73-97. Cambridge University Press. Cambridge, UK.

Gentry, A.H. and C. Dodson, (1987). Contribution of nontrees to species richness of a tropical rain forest. Biocropica, 19: 149-156.

Gerwing, J.J. and D.L. Farias, (2000). Integrating liana abundance and forest stature in to an estimate of total above ground biomass for an eastern Amazonian forest. Journal of Tropical Ecology 54:5-9.

Gianoli, E., A. Saldana, M. Jimenez-Castillo and F. Valladares (2010). Distribution and abundance of vines along the light gradient in a southern temperate rainforest. Journal of Vegetation Science 21: 66-73.

Gilbert, B., S.J. Wright, H.C. Muller-Landau, K. Kitajima and A. Hernández, (2006). Life history trade-offs in tropical trees and lianas. Ecology 87: 1281-1288.

Hegarty, E.E. and E. Caballe, (1991). Distribution and abundance of vines in forest communities. In: F.E. Putz\& H.A Mooney (eds.) The biology of vines, Cambridge university Press. p. 313:335

Henry, A.N., V. Chithra and N.P. Balakrishnan, (1987). Flora of Tamil Nadu, India, Series -I: Analysis, Vol.2. Botanical survey of India Coimbatore.

Krings, A. (2000). A phytogeographical characterization of the vine flora of the sonoran and chihuahuan deserts. Journal of Biogeography 27: 1311.1319.

Lusk, C.H. (2002). Leaf area accumulation helps juvenile evergreen trees tolerate shade in a temperate rainforest. Oecologia 132: 188-196.

Lusk, C.H., R.L. Chazdon and G. Hofmann, (2006). A bounded null model explains juvenile tree community structure along light availability gradients in a temperate rain forest. Oikos 112: 131-137.

Malhi, Y. and J. Wright, (2004). Spatial patterns and recent trends in the climate of tropical rainforest regions. Philosophical Transactions of the Royal Society: Biological Sciences 359: 311-329.

Matesanz, S., E. Gianoli and F. Valladares, (2010). Global change and the evolution of phenotypic 
plasticity in plants. Annals of the New York Academy of Sciences 1206: 35-55.

Mathew, K.M., (1983). The flora of Tamil Nadu Carnatic (Madras, Diosceesam Press).

Morley, B.D. and H.R. Toelken, (1983). Flowering plants in Australia. Adelaide. Rigby

Muthuramkumar, S. and N. Parthasarathy, (2000). Alpha diversity of lianas in a tropical evergreen forest in the Anamalais, Westtern Ghats, India. Diversity and Distributions 61-14.

Nair, N.C. and A.N. Henry, (1983). Flora of Tamil Nadu, India, Series I. Analysis Vol.I, Botanical Survey of India, Coimbatore.

Parsons, R.F., (2005). Notes on the origins of Australian desert vines. Adansonia 28: 405-412

Parthasarathy, N., S. Muthuramkumar and M.S. Reddy, (2004). Patterns of liana diversity in tropical evergreen forests of peninsular India. Forest Ecology and Management 190: 15-31.

Perz- Salicreep, D.R., V.L. Sork and F.E. Putz, (2001). Lianas and trees in a liana forest of Amazonian Bolivia. Biotropica 33: 34-47.

Phillips, O.L., R.V. Martinez, L. Arroyo, T.R. Baker and T. Killeen, (2002). Increasing dominance of large lianas in Amazonian forests. Nature 418: 770-774.

Phillips, O.L., R.V. Martínez, A.M. Mendoza, T.R. Baker and P.N. Vargas, (2005). Large lianas as hyperdynamic elements of the tropical forest canopy. Ecology 86: 1250-1258.

Putz, F.E. and H.A. Mooney, (1991). The biology of vines, Cambridge, UK: Cambridge University Press.

Rowe, N. and T. Speck, (2005). Plant growth forms: an ecological and evolutionary perspective. $\mathrm{NeW}$ Phytologist 166: 61-72.

Rundel, P.W. and T. Franklin, (1991). Vines in arid and semi-arid ecosystems. In: Putz FE \&
Mooney HA (eds.) The Biology of vines p. 337356. Cambridge: Cambridge university press.

Saldana, A. and C.H. Lusk, (2003). Influencia de lasespecies del dosel en la disponibilidad de recursos y regeneraciónavanzada en un bosquetempladolluvioso del sur de Chile. Revista Chilena de Historia Natural 76: 639650.

Schnitzer, S.A. and F. Bongers, (2002). Lianas and gap phase regeneration: implications for forest dynamics and species diversity, In: F. Bongers: M.P $>$ E $>$ parren\& D. Trasore (eds.) Forest climbing plants of West Africa Diversity, Ecology and Management CABI Publishing p. 59-72.

Shmida, X., (1985). Biogeography of the desert flora, In: M. Evenari M. Noy Meir. I \& Goodall DW (eds) Ecosystems of the World, Vol.12A, p.2377, Amsterdam Elsevier.

Sridhar Reddy, M. and N. Parthasarathy, (2003). Liana diversity and distribution in four tropical dry evergreen forests on the Coromandel Cost of south India. Biodiversity and Conservation 12: 1609-1627.

Swaine, M.D. and J. Grace, (2007). Lianas may be favoured by low rainfall: evidence from Ghana. Plant Ecology 192: 271-276.

Tackholm, V., (1974). Student's Flora of Egypt, $2^{\text {nd }}$ ed. Cairo: Cairo University Press.

Vander Heijden G.M.F., J.R. Healey and O.L. Phillips, (2008). Infestation of trees by lianas in a tropical forest in Amazonian Perú. Journal of Vegetation Science 19: 747-756.

Wright S.J., O. Calderón, A. Hernández and S. Paton, (2004). Are lianas increasing in importance in tropical forests? A 17-year record from Barro Colorado Island, Panamá. Ecology 85: 484-489. 